\title{
Raising the returns to venture finance
}

\author{
Charles Baden-Fuller ${ }^{\mathrm{a}, *}$, Alison Dean ${ }^{\mathrm{b}}$, \\ Peter McNamara ${ }^{\mathrm{c}}$, Bill Hilliard ${ }^{\mathrm{d}}$ \\ ${ }^{a}$ Cass Business School, City University, London EC2Y 8HB, England, United Kingdom \\ ${ }^{\mathrm{b}}$ Canterbury Business School, University of Kent, Kent, England, United Kingdom \\ ${ }^{\mathrm{c}}$ University College Dublin, UCD Business Schools, Department of Management, Belfield, Dublin 4, Ireland \\ ${ }^{\mathrm{d}}$ Sol C. Snider Entrepreneurial Research Center, Wharton School, University of Pennsylvania, United States
}

Received 1 April 2003; accepted 1 February 2005

\begin{abstract}
Investors in ventures that threaten to disrupt the markets of incumbents can use the options markets to add value to their investments by purchasing put options on the stock of the disrupted rivals on the basis of their asymmetric knowledge. By making a profit on these derivative trades in the stock of the disrupted firms, the investor innovator is able to recapture from the market extra and immediate profits (equivalent to the value of the consumer surplus) generated by the innovation. These additional profits increase the incentive of investors to invest in disruptive ventures and so correct biases that have been observed against investing disruptive innovation. Our paper provides guidance as to how these effects arise and their value. It also explores the ethical, regulatory and practical constraints on undertaking the trades, pointing out that it is effective and the legality seems to be robust provided certain conditions are met.

(C) 2005 Elsevier Inc. All rights reserved.
\end{abstract}

Keywords: Venture finance; Options; Disruptive ventures

\footnotetext{
* Corresponding author.

E-mail addresses: c.baden-fuller@city.ac.uk (C. Baden-Fuller), a.dean@ukc.ac.uk (A. Dean), peter.mcnamara@ucd.ie (P. McNamara), bill@alum.mit.edu (B. Hilliard).
}

0883-9026/\$ - see front matter (C) 2005 Elsevier Inc. All rights reserved. doi:10.1016/j.jbusvent.2005.02.009 


\section{Executive Summary}

The returns to venture finance are skewed and uncertain. Research in this journal suggests that most new ventures fail and overall less than 1 in 10 new ventures make a positive return (Mason and Harrison, 2002; Mainigart et al., 2002; Kleiman and Shulman, 1992; Bygrave, 1989). The fact that so many investments fail makes it hard for would-be entrepreneurs with good propositions to attract seed money. We explore how would-be investors can increase the returns on their portfolios by making subsequent investments that are correlated to the activities of their initial investments. What at first sight may seem to be an exclusively financial strategy holds great importance for entrepreneurs, as it increases the availability and willingness of financiers to invest in new ventures.

The central idea is that the venture investor can take advantage of potentially valuable asymmetric information about the actions of the firms in which they have invested (Aboody and Lev, 2000). This information relates to the timing and potential efficacy of the effect of the invested firm's actions on its established rivals. For example, the firm may be a new entrant that is about to launch a product that satisfies market requirements better at a considerable discount to current market pricing. Such actions have the potential to change the competitive landscape and so reduce the value of established rival firms. When those rival firms are quoted and traded, the venture financier can capture additional value by trading in financial options in the rivals' stock.

Let us explain the situation more clearly. We are concerned with the subset of all new businesses that directly threaten well-established rivals. This is a broad class of situations that we call "disruptive" and is far more extensive than the narrow class of technologically disruptive innovation (Christensen, 1997). New businesses that could disrupt competitors in established markets have difficulties in finding investment. This is because investors and entrepreneurs are legitimately concerned that the well-established rivals may react aggressively in retaliation (see McGrath and MacMillan, 2000). Even though consumers may benefit from the disruption because of better products, better services, or lower prices, gains from investments in disrupting firms may be elusive. Our paper notes that investors in these "disrupting" innovations can be more positive towards their investments because they can capitalise on how financial markets react to threats, even when the actual event is distant. By taking certain actions early on in the investing process, investors in the new venture can raise the returns on their investment.

The sequence of events is broadly as follows. Armed with the knowledge of the situation of the disrupting firm in which it has a stake, the first step for the investor is to establish the rights to trade. The investor does this by adding to their investment "term sheets" explicit information rights permitting them to utilize any information learned about unrelated third parties as a result of their investment in the firm. The investor then goes about exploiting the information. It first identifies which third-party firms will be adversely affected by the disruptive company's innovation. Shortly before the innovator firm disrupts the identified third-party firms' markets, the venture financier purchases put options (or similar derivative instruments with equivalent effects) on these rival firms before the impact of the knowledge of the disrupting firm is widely known or appreciated. In due course, the disrupting firm will announce that its product-process and/or market 
penetration has progressed to the point where its deleterious effects on the future profits of the rivals are obvious to the investing public. As the financial markets integrate this information, the rivals' stock prices will fall. The investor is then able to exercise the options (cash-in the derivatives) at a profit.

Only cetain ventures fit the demanding criteria of this paper. We are only dealing with innovations that are capable of influencing market structures and stock prices of rivals. Although there is no requirement that the firm that is causing the disruption is listed for the strategy to work, the stock of the threatened firm (the "disrupted firm") must be traded in well-developed financial markets. Since a large proportion of the US and European economies are populated by quoted firms, and a significant goal of venture financiers is to capture the maximum profit from the rights and preferences negotiated into their investments, our paper has potentially a wide applicability.

We begin the paper by examining the critically important ethical question of whether the strategy has the potential to increase public welfare as well as the purse of the investor. We discuss at some length regulatory and institutional issues. We refer to legal journals and US Supreme Court decisions to show that, in general, our strategies do not appear to fall foul of SEC and other regulatory rules. Our analysis also discusses the transaction costs of the proposed strategies, the impact of stock price volatility, and issues of timing.

\section{Introduction and Background literature}

There is a substantial literature on the use of asymmetric information possessed by managers when they trade in the stock of their own firms for personal gain: such activities are typically labeled insider trading or trading on private information. The extensive discussion that appears in the finance, economics and management journals generally concludes that the welfare gains to such behaviour are related to making information in markets more efficient (see for instance Manne, 1966; Bebchuk and Fershtman, 1994; Hu and Noe, 2001). Recent papers have gone further and have questioned whether there are any systematic losers from trading based on asymmetric information because markets are friction-laden. Such work has typically used real data in real markets (e.g. Pagno and Roell, 1966; Jeng et al., 1999). This work in no way denies that there will be specific losers in particular trades, but rather that writers of option contracts do not lose overall in the long run. Despite these papers, the legal position is that insider trading is outlawed in most developed economies.

Our case here is quite different: we are considering the use of what is technically known as trading in stock substitutes, that is, the use of information that one investor possesses from his relationship with a firm in which he/she has invested that affects the stock price of another legally and institutionally unrelated firm. Diligent enquiry and a wide search have indicated that this dimension has only rarely been discussed, and then only in the law journals rather than those relating to finance and strategy (Ayres and Bankman, 2001). This literature has stressed the cases where the information may have been gained in dubious circumstances and has ignored the situation of investors in disruptive innovations getting information legitimately through their corporate governance exposure and diligence related to the firms in which they have invested. 
In this opening section, we wish to focus attention on the (economic) welfare implications of investors in disruptively innovating firms trading in stock substitutes. Because the proposed trading strategies might be considered controversial, it is appropriate that this question be dealt with at the very start of the paper and not consigned to an endnote. Because the question is technical, we use the economists' tool kit as a way of considering questions of welfare and values.

Economists have often argued that investors in innovations need some protection. The argument is usually portrayed in the context of defending patent laws. Here we deploy the argument to defend our trading strategy. Our argument also allows us to measure quite precisely the gains involved and connect these gains to the welfare issues. We start with the discussion of the causes of the poor returns to innovation set out by the Nobel Laureate Kenneth Arrow (1962). He pointed out the paradoxically destructive role played by competition. When a firm introduces disruptive innovation that threatens the survival of competitors, subsequent competition can force down prices and reduce the profits available to the innovator. The threat is greatest when the innovator has no patents and cannot erect entry barriers. The competition can come from existing firms or new firms that respond to the innovation. Competition, normally considered to be a blessing for consumer welfare, can be adverse because the investor may not be able to capture the returns to the innovation fully, even when the innovation is "socially desirable". Arrow showed that this danger would discourage investment in many radical innovations and consequently the innovation may not be launched. The argument relied on a careful analysis of consumer surplus.

The problem that Arrow identified can be overcome in part or in full if inventors can make direct contracts with customers in advance. Customers can promise to the inventor that $\mathrm{s} /$ he will receive his/her rewards either directly through purchase contracts at a predetermined price, or by side payments. Von Hippel (1986) has pointed out that in many producer goods markets, such contracting does occur on either a formal or an informal basis. Hirshleifer (1961) has pointed to other ways of getting at the consumer benefit: the innovator can make contracts with the suppliers of complementary goods to make the gains. Thus he argued that Eli Witney, the inventor of the cotton gin, would have made exceptional profits if he had abandoned his attempts to patent the machine and instead focused attention on investment substitutes by buying up land suitable for raising cotton, which, at the time, was trading at very low prices.

Our proposed strategy for investors is another way around the problem identified by Arrow (1962). Investors who hold stock in the disrupting firm trade in the stock of the unrelated disrupted firms. Our strategy therefore builds on a long line of discussion about how investors in innovations can improve their returns with ingenious strategies.

\section{The model}

\subsection{The assumptions}

Consumer surplus is a concept invented by Alfred Marshall that measures the difference between the amount that consumers might be willing to pay (the value) and the 
amount that they actually pay (the market price). To show simply how this concept is used, let us go back to Arrow (1962). He explained that most innovators see poor returns because they are unable to capture all of the additional consumer surplus (the consumer benefits) generated by their innovations. The consumer surplus is lost to the investor because the innovating firm has to lower prices to sell the product. This lost consumer surplus dulls the returns from innovation. Furthermore, the innovator has to run the risk of rivals copying the innovation when there are either no property rights in the innovation, or the property rights are imperfect in their coverage.

We will build a simple model that examines how trading options on the stock of rival firms can improve the welfare of society and the returns to investors in the case of disruptive innovations. We begin with a very simple model (and we later discuss how to generalise the results). We assume that there are only two players, A and B. A is the innovating firm that plans to introduce a new cost-reducing disruptive process to the market. B is the incumbent firm (or group of firms). Since A's innovation lowers costs, A anticipates that after launch B's product prices will fall. Such price behaviour is justified from theory considerations (Arrow, 1962). This is reinforced by empirical studies which have observed the negative impact upon an incumbent's market value that an announcement of disruptive innovations from rivals (Sundaram et al., 1996), or the actual launch of rival products that are strategic substitutes of the incumbent's products (Chen et al., 2002; Whinston and Collins, 1992).

Definitions. In the first part of the paper we define a "disruptive" innovation as an innovation that allows a new entrant to supply a product or service at a lower cost than the established incumbent firms. We later extend our definition of disruptive innovations to include all innovations that have the potential to alter the price of the stock of an incumbent firm.

Fig. 1 presents the standard micro-economic treatment of this situation (with the standard assumption that A exploits its technology and shares the market with B). The

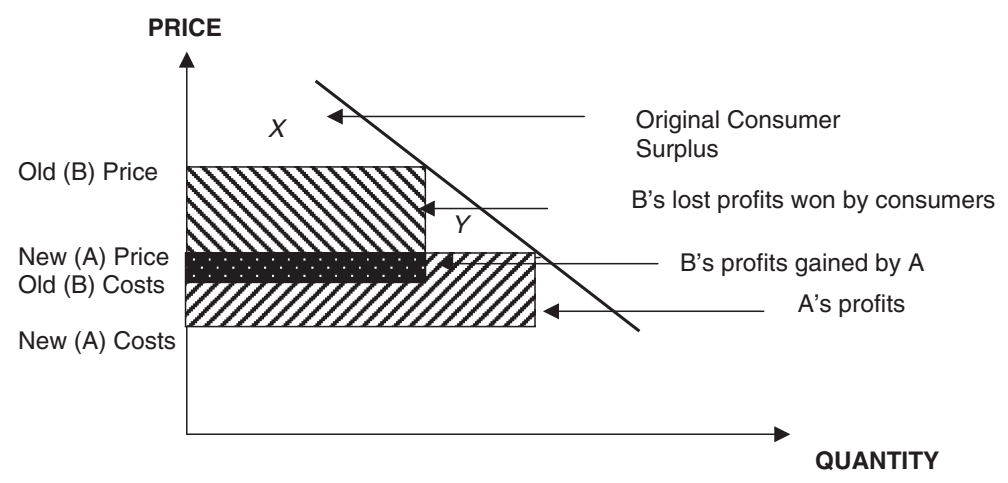

A licenses to B its technology, so that B keeps some profits and shares the market with $A$.

Fig. 1. Measuring the gains using consumer surplus. 
diagram also allows us to track consumer surplus (which is the consumer's welfare not captured by either the producer's costs or the producer's profits). The original consumer surplus before A's arrival is represented by the area between the upper part of the demand curve and the old price line (space marked X). Following the entry the consumer surplus has increased because the price has fallen, and the sum of "B's lost profits" and the area of the white triangle (space marked Y) represent this. (As is well known, the area of the Y triangle is small compared to "B's lost profits".)

We suppose A has a total monopoly on the innovation; that there is no information leakage; and that B's stock is traded. When A makes its discovery, there is a time during which this knowledge is not widely disseminated or appreciated. At that time, when financiers of A learn about the innovation (via the investment-related contracts they have with A) they can place a bet on B's share price falling, buy a derivative instrument on B's stock price, or sell the stock of B short. They know that when knowledge of A's project becomes widely disseminated, B's stock price will be adversely affected. The investor can then realise profits from the arbitrage they have set up.

The instruments available to the investors in A to gather this benefit are quite broad. They can sell stock short; they can make bets or they can purchase a put option. We can be more precise. A short sale is exactly equivalent to (1) purchasing a put option plus (2) selling a call option for the same maturity and strike price less (3) the cash sum of the strike price discounted at the risk free rate from the time of expiry of the options. This equivalence is determined by the principles of arbitrage, and is independent of the assumptions of Black and Scholes (1973).

We will explore later in the paper the various risks from selling short as opposed to buying puts. Here we merely note that in practice, to limit risk, the investors in A should purchase a put, a strategy that for a small fee (the loss of the revenues from writing the call) eliminates the risk of being "wrong footed" about price changes.

Proposition 1. Investors in companies creating disruptive innovations can improve the returns to their investment by utilizing asymmetric information and purchasing put options or similar contracts on the stock of rival firms before knowledge about the success of the disruptive innovation is widely known.

\subsection{Valuing the gains from a theory perspective}

Using the concept of consumer surplus, we can quantify the gains. The profit from the option trading for those investing in A depends on the significance of A's innovation. We assume that the innovation is disruptive, but not to the extent of driving B out of business. In this case, the gains in the option trading will closely reflect B's lost profits. The more the innovation affects B's stock price, the greater the gain to A. In Fig. 1 we assumed for simplicity that $\mathrm{B}$ has a constant average-marginal cost curve. We also assume that A's project impinges exactly on B's space (in economics terms its technology is a perfect substitute). In this case the lost profits to B are a significant part of the consumer welfare gain. As we show later, neither of these two assumptions is necessary to obtain the key result.

It may be that A's innovation is so significant that B is driven out of the market. This case is shown in Fig. 2. The gains from the put option are no longer equal to the change in 


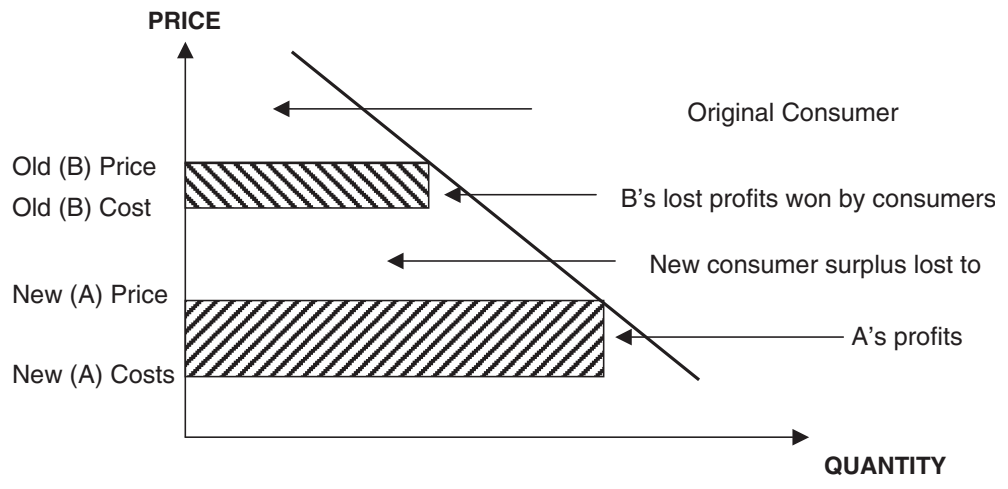

A drives $B$ out of the market.

Fig. 2. Measuring the gains from dramatic innovations using consumer surplus.

the consumer surplus, because B's stock cannot be traded at a negative price. If the market price falls below the point at which $\mathrm{B}$ is driven out A cannot re-capture that portion of the consumer surplus generated below a zero price for B's stock.

Providing financial markets accurately gauge B's losses following A's entry, then the gains from the put option to the investors in A represent a large part of the change in consumer surplus following the disruption by $\mathrm{A}$. This means that the financial transaction "completes the market for knowledge" and so provides a source of the lost profits identified by Arrow (1962). Significantly, apart from the small white triangle of benefits, there are no other true gains available, for all the consumer surplus is "used up". 1

Proposition 1a. The maximum gain to the investor from the exercise of the put option on the rival firm is roughly equivalent to the un-appropriated consumer surplus following the launch of the innovation minus the costs of making the put option.

\subsection{Generalising the results}

Appeal to Coase's theorem allows us to see the result in a different way and to appreciate the generalisation of the result (and relaxation of the initial assumptions) to cases where the innovation is not one of simple cost reduction but includes product and market innovations. According to Coase (1960) market forces ensure that the optimal allocation between producer and consumer will occur provided information is perfect and transactions are costless. Where this is not the case, incomplete contracts between producer and consumer will lead to sub-optimal allocation. The problem facing $\mathrm{A}$ is that

\footnotetext{
${ }^{1}$ If $\mathrm{B}$ has been able to practice price discrimination among users, by techniques such as tying, metering or franchising, then the benefits of the welfare triangle are also captured. Such practices are only legal in certain instances that need not be explored here.
} 
the value of the discounted cash flow of the project does not capture the value of the consumer surplus resulting from the introduction of the innovation.

If A can obtain contracts from the customers of B in advance of its innovation, it can capture the surplus. The extent to which such advance contracts are possible depends on the extent to which customers believe that innovations will occur without their having to engage in such contracts. In practice, except where firms are vertically integrated with customers, constructing contracts with users is very difficult. However, the capital market has clear expectations about future customer behaviour. The market capitalisation of B reflects the capital market's assessment of the loyalty of the customers via the discounted future earnings of B. In Coase's terms, purchasing a put option on B forms a contract with speculators about this loyalty because B's stockholders already have strong expectations about B's future profits from its customers. The put option is a surrogate contract with B's customers, overcoming the incomplete contract problem and enabling A to extract the surplus.

Coase's theorem allows us to appreciate that working the capital markets allows A to capture the value of the consumer surplus in the more general case. For example, if A's innovation impacts many rivals, then buying a set of put options on all of the rivals will allow A to capture the value of the lost consumer surplus. More importantly, A cannot capture more consumer surplus than exists, and it will capture (effectively) all there is to be had (less transactions costs).

Sometimes A will create an innovation that has complementary provider benefits. For example, if A is innovating a new system for stock trading that benefits the providers of complementary information such as Reuters, then A can capture some of these gains by buying call options on the providers of complements. Stock prices of complementary providers will rise following the announcement. Again, appeal to Coase's theorem allows us to see, without complex mathematics, that there is no double counting.

Proposition 1b. In general, where A's innovation has both complementary and substitution effects on a variety of other firms (i.e., on stock substitutes), the investors in A can capture the value of the lost consumer surplus by buying a basket of suitable call options on complementors and put options on rivals.

\subsection{What the consumer surplus argument shows}

Propositions $1 \mathrm{a}$ and $1 \mathrm{~b}$ help us measure the potential social benefits of the trades that the investors undertake. From the investor's perspective, the financial trade captures most of the surplus (consumer benefit) that is not captured by A when A sells its disruptive product in the market. In extreme cases, the options trade makes an unprofitable, but socially worthwhile, investment realisable. In any case, the options trade yields a more immediate cash benefit that is additional to the rather uncertain and more distant returns otherwise inherent in such an investment. Thus there will be cases where the options trade will allow projects to be financed that could not be financed otherwise (except perhaps by government subsidy). As noted above, such cases will improve society's welfare (as seen by the economist's measure of consumer surplus).

Who pays for the trades? The consumer does not pay directly; it is the issuers of the instruments. In most markets, the sellers of put options and derivative instruments are 
pension funds, who undertake the positions in the hope of increasing their returns. Where pension funds represent the same class of consumers as the future users of B's current products, the put option is a surrogate contract with B's customers. In other cases, pension funds or speculators are merely standing in for the consumers. In Coase's terms, we are bridging the financial markets for B with the asset markets for A's invention.

It must be stressed at this point that there is a big difference between trading in derivatives on rival companies (stock substitutes) to help finance innovations and the use of insider knowledge to reap personal gain. Societal gains from insider trading are usually measured in terms of more efficient trading on financial markets and more efficient signals. These gains are widely disputed, have significant agency problems and create ethical concerns. In contrast, trading by investors in stock substitutes to help finance disruptive innovations is more clearly socially beneficial in the sense that there are no agency problems. The profits earned from these trades directly and unambiguously benefit financiers of the innovation process, thus solving the dilemma observed by Arrow (1962). Moreover the economist's metrics allowing us to judge these benefits are rooted in a long tradition of welfare calculations used by economists since Alfred Marshall.

In summary, the use of options augments value. Judging a venture investment solely on the basis of its expected cash flows would be misleading if the gains to be made from the exploitation of rivals' losses were not taken into account. Further, disregard of these gains can lead to sub-optimal returns to the investor. In the final analysis it is the combination of the value of the discounted cash flow (DCF) of the investment and the gains from the paired action in the financial markets which determines the true value of a potential investment in the disruptive innovator, A.

\section{Importance of the put option relative to the DCF}

How important is the value of trading the financial options we propose relative to the profits from the underlying disruptive investment? The answer is that the value could be very large. Profits from the option trade could be many times the total future profits from the original investments in the company undertaking the disruption. We begin by looking at four case examples: airlines, computer peripherals, medical devices and drugs. Then we look at empirical papers that have observed the negative impact that announcement of new potential or actual disruptions have upon the market capitalisation of incumbents.

Whinston and Collins (1992) monitored the effect of 24 announcements by the airline People Express. Each announcement was a stated intention to enter new US domestic routes between two cities during 1984-1985. They found that each announcement had a significant negative effect on the market capitalisation of incumbents and a significant positive effect on the price of People Express's stock. The fall in any given incumbent's stock price was about four times larger than the gain in stock price experienced by People Express at the time of the launch. This suggests that the potential gain from trading put options (or some equivalent derivative) may be larger than the potential gains from the DCF of the investment itself. Even more critically, the gains from the put arise immediately, whereas the project gains (from the management perspective) are spread over 
the life of the project. To reinforce the point, we know that investors in People Express ultimately lost money on their shares, but they could still have made a profit if they had been able to undertake the financial play.

In 1987, a venture capital-backed company named Phoenix Technologies, then private, announced that it was planning to launch a product that would disrupt Adobe's postscript printer technology. On the announcement, Adobe's stock dropped over 36\% over a 2month period. Investors in Phoenix Technologies could have increased their return by purchasing at a suitable time a put on Adobe's stock (provided they did not have any other relationship with Adobe, see the regulatory section below).

In the medical device industry, on September 17, 2003 it became clear that a device called a "drug-eluting stent" from Boston Scientific would be a disruptive technology to a division within the giant pharmaceutical company Johnson and Johnson. The stock of J\&J fell $1.4 \%$ in $15 \mathrm{~min}$ and $2.5 \%$ in that day. Moreover, the stock price of the S\&P 600 Smaller Cap SurModics (Nasdaq: SRDX) dropped 13.7\% that day because, at the time, SurModics supplied the technology to J\&J that was used in its "drug-eluting stent". (The stock in Boston Scientific was suspended during the announcement period.) Investors in Boston Scientific, after taking appropriate precautions, could have increased their wealth by purchasing put options on either SurModics or on J\&J at the appropriate time.

An example of complementary benefits can be seen in the pharmaceutical case of Barr Laboratories. On July 12, 2001, Aai Pharma announced that it had received a US patent for a form of fluoxetine, the active ingredient in Prozac. Aai Pharma also announced that it had licensed fluoxetine to Eli Lilly for marketing. Eli Lilly simultaneously announced its decision not to request FDA (Food and Drug Administration) approval for the new form of Prozac thereby opening the door for the production of generics to Prozac. The combined effect of the two announcements was both complementary and threatening. Barr Laboratories found themselves first-to-market in the US with a generic rival to Prozac. Barr's stock jumped $10 \%$ in the first day, and a further $24 \%$ during the following 42 -day period. Eli Lilly's shares lost nearly $2 \%$ in the first day. Borrowing from data supplied by John Graham (Fraser Forum: September, 23 2000) we can see that the investors in Barr gained about $\$ 34$ millions whereas the investors in Eli Lilly lost more than \$1 billions, once again showing that the wealth impact on the disrupted firm can be much greater than that accruing to the disruptor.

In each of the above cases, the investors in the companies creating the disruptive innovations potentially had early insights into the market dynamics. These insights, whilst not absolutely guaranteed in their effect, provided solid investment opportunities for the investors to increase their returns.

Sundaram et al. (1996) examined the impact that 106 announcements of changes in R\&D activities by firms from 18 industries had on both the firm and its rival. They found that where the $R \& D$ activity was characterized as generating possible strategic substitutes to incumbent firms products that the incumbents experienced negative and statistically significant reductions in stock market value. The announcing firm experienced significant, positive rises in market value.

Building on the work of Sundaram et al. (1996), Chen et al. (2002) provide further support for the effect of announcements on the stock price of disrupted firms. Employing a 
dataset of 384 new product announcements by firms from 39 industries, they found that where a new product launch announcement was viewed as a strategic substitute for an incumbent product, the incumbent experienced negative and statistically significant reductions in its stock market value within a narrow 2-day window. The announcements studied by Chen et al. (2002) were not just disruptive technologies but also non-disruptive ones too, the competitors were defined by a wide industry definition rather than a narrow product-based criterion, and the test of the price fall was restricted to a narrow 2-day window in comparison to a 260-day benchmark which might be more typical of an options contract. The test is therefore much more demanding than that which our investors need. It should also be noted that in each of these studies, many of the firms were diversified and that diversification had no effect on the issue at stake.

Proposition 1c. Placing options contracts under conditions of asymmetric market information has the potential to increase the returns to investors in innovations many times, where the benchmark is the DCF of the investment solely in the innovation itself without capitalising on externalities.

This brings us to another point: investors in firm A may not be confident that it will succeed in disrupting B, but they can still benefit from the asymmetric information if $\mathrm{A}$ has many close rivals also working on the same challenge. Disruptive innovators come in packs; typically there are many firms working on parallel tracks. Realization that a breakthrough is about to occur may persuade the market that B's value is under-threat even if the market may not know which of the firms in the pack will win. Studies of disruptive innovations, such as by Christensen (1997), give examples of these phenomena.

\section{Timing, information leakage, transactions costs and uncertainty}

Until now we have ignored several important factors such as the carrying costs of purchasing options, the danger of information leakage from the disrupting company, the volatility of the stock price of the disrupted company and uncertainty over the effects of the disclosure. These factors might interact in a damaging manner to affect both the size of the gains and the timing of investors moves. For example, if the rival firm B has a very volatile stock price, due to other factors such as raw material price volatility, and if the time between buying the option and cashing in the bet is long, there is a danger that the price of the stock will rise on account of other factors even after the market has taken account of the bad news. We will deal with the problem in several stages. First, what are the chances of making a profit on the derivative trade for a given situation? Then, what factors determine the timing of the buying, holding and selling of the derivative?

\subsection{Price volatility}

First, we note that we must consider the volatility of the stock price of the rival firm on whose stock we place the trade. A higher volatility means a better chance of the price rising in such a way as to nullify the effect of our announcement. We also note that there is a volatility of the expected effect of the announcement. If the information we release to the 
market is ambiguous, the market may not react as much as we hoped and so the gains may be less. If $E$ is the expected value to be gained from depressing the stock price of B the disrupted firm, and $c$ the transactions cost of the put and $T$ the time that the option is left open, then the expected return can be stated as:

Gain is : $E-c T$

Sophisticated investors who are rich (as is often the case) will clearly take into account that any put option has a chance of making a gain. Indeed, the typical sophisticated investor is likely to assume the options are correctly priced by the market; and that the true transactions costs are actually much less than the price of the put, even approaching zero. Such an investor (say a typical venture fund) is therefore unlikely to perceive much downside risk from the speculative trade. Moreover, if the investor acts like a venture fund the risk will be one that is well understood and no more risky than many other investments that the fund makes. $E$ may turn out to be small, but if $c$ is small nothing will be lost.

In contrast, the naïve risk-averse investor will not only be interested in the expected gain, but also concerned with the likelihood of a loss, and may take a much more conservative view. To this investor, $c \cdot T$ may not be a trivial sum. The likelihood of loss is dependent on the volatility of the stock price of the rivals $B$ and the volatility of the effectiveness of the announcement $E$ as well as the size of $c \cdot T$. As a first-order approximation, these risks work in an additive manner (because they are independent events). Let us use a simple example of the naïve risk-averse investor wishing to be $95 \%$ certain of making a gain to see how the numbers work out. If SB is the standard deviation of the variation of the price of B per period and if SA is the standard deviation of the expected effect of the announcement (which is absolute) then the investor wanting to limit risk to $5 \%$ should play as long as:

$$
E>2 S A+(2 S B+c) T
$$

\subsection{Determinants of the timing}

The size of $T$ is a critical factor in the potential profits of the trade and the risk of the trade. A short $T$ limits transactions costs and risk. A long $T$ has the opposite effect. What determines the value of $T$ ? The simple answer detailed below is that $T$ is determined by an interaction between the carrying costs of the put and the rate at which information is leaked. (Once the information is leaked, the market reacts speedily.) Even in semi-efficient capital markets all public announcement that impact on the present and future earnings of a stock is promptly absorbed via changes in the stock price (Fama, 1991). A number of studies have observed that the effects are almost complete within as little as 2 days in the case of stock substitutes (Chen et al., 2002; Sundaram et al., 1996.) And, as noted above, the carrying costs for the put are comparatively less for the sophisticated investor than the naïve one.

Fig. 3 shows the issues and solution to the effect of carrying costs and information leakage diagrammatically. On the vertical axis we plot the cumulative value of the information to the various parties and the cost of the put, which we assume as constant over time. Time is shown horizontally. The cumulative value of the information is 


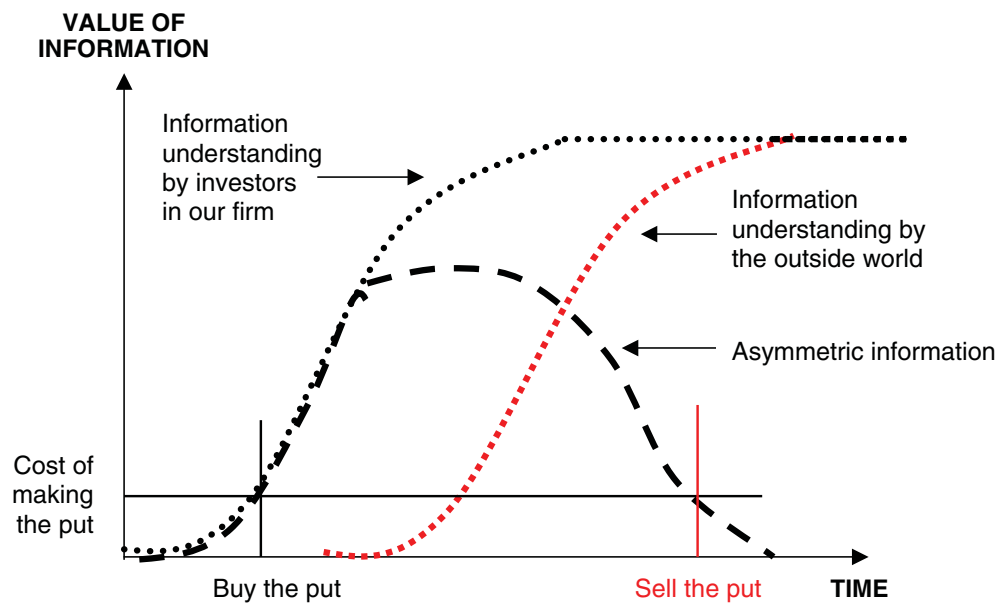

Fig. 3. Information asymmetry and transactions costs.

measured as the total impact on the market capitalisation of the disrupted firm B. As noted, we assume that the true impact of the information is clear to the investors of the innovating firm prior to its becoming clear to the financial markets (in particular the stockholders of B). Our diagram shows the typical S shaped information curve, but the curve could have any shape. It also shows that the diffusion (of the significance of the) information between A and B's stockholders occurs at a constant rate; again this is only for ease of exposition and does not affect the result. The important point is that there is some time lag between the two curves.

From the figure it is easy to see that gains are maximised by buying the put at the earliest point in time where the value of asymmetric information is equal to the cost of carrying the put. Likewise, the best moment to sell is when the two are again equal. Optimal purchase of the put is not at the point at which asymmetric information is at its greatest, as the casual observer may have expected. We can generalise our result to the standard first-order derivative equation summarized in the proposition below.

Proposition 2. The optimal strategy for the investors in $A$ is to purchase the put when the value of the information asymmetry just rises above the carrying cost of the put. Likewise, the investors in A should sell the put when the value of the information asymmetry falls to just below the carrying cost.

In practice, knowledge of potentially disruptive innovations is often well known before the market takes notice. There are many smaller companies experimenting with innovations at any one time. Their investors attend board meetings and conduct regular discussions with management. These sources of information give company A's investors regular feedback on the company's prospects relative to that of its competitors. The moment when industry conferences give platform visibility to the activities of these firms is when the knowledge becomes effective and is noticed by financial markets. Another way of gaining attention is to form an alliance with credible partners. The stock market has reacted positively to announcements of alliance formation by small firms with larger 
partners (Chan et al., 1997; Das et al., 1998; Koh and Venkatraman, 1991.) This means that in practice there is a long time during which the investors in the disruptive technology have a moment to place their bets.

What are the approximate transactions costs one might expect? To provide a tangible example of a real venture situation, we give some data for investors in a new book-selling business trading put options on a well-traded stock substitute that has a narrow portfolioBarnes and Noble. We looked at Barnes and Noble (www.ee-online.com) (symbol: BKS) put options with various expiration dates on August 23rd, 1999, when BKS's \$25 stock price was equivalent to the strike price of the options. BKS options with 2-month, 5-month and 8-month expirations became profitable with only $2 \%$ stock-price drops. Indeed, suppose one was to believe that the announcement could move the stock price of BKS by say $6 \%$ in $1-2$ months, or $13 \%$ in $5-8$ months, then this example indicates a potential to earn greater than $30 \%$ cash-on-cash returns; and very high internal rates of return $(480 \%$ and $150 \%$, respectively). It is easy to see that a modest outlay in this arena would greatly improve the return on the venture investment as a whole.

\section{Regulatory and legal issues}

Some have expressed concern that our proposed strategies for the investors are not legal. The concerns centre on the fact that investors in A are using non-public information to make a gain on the change in the stock price of the threatened firm B. In other words, the use of "material, non-public information" gained through an investment in a "Disruptive private company A" would violate insider trading laws related to trading publicly traded stock in "The disrupted public company B." We have carefully trawled the insider trading statutes in the US, and have discussed our example with lawyers and experts. Whilst we are not legal scholars, there is clear U.S. Supreme Court case law and commentary to support our position that the strategy we propose is legal. We particularly refer to United States v. O'Hagan (1997) and to Ayres and Bankman (2001), who explicitly discuss the legality of trading in stock substitutes. Neither the Supreme Court case nor Ayres and Bankman discuss our example of venture investors increasing their returns to help finance disruptive innovations, but they both discuss the more general case of holders of material, non-public information on a company with which they have no legal connection who choose to trade on that information for personal benefit.

\subsection{SEC Statutes}

Because we are dealing with legal issues, it is necessary to use some legal terminology that clarifies the situation more exactly and supports our view that the legality is robust. The applicable United States Statute is Rule 10(b)-5 of the Securities Exchange Act of 1934. This rule states that one cannot "engage in any act, practice, or course of business which operates or would operate as a fraud or deceit upon any person, in connection with the purchase or sale of any security..." However, as far as our case is concerned, to infringe this law, one must either be privy to material, non-public information known to 
insiders in "Disrupted public company B" or one must have misappropriated material, nonpublic information about "Disrupted public company B" (unknown to insiders) from an "outsider" who is somehow the owner of such information.

Our investors in the disruptive company A should not fall foul of any of the SEC rules if they take care of the following: (i) they must owe no duty to B or have any temporary or permanent relationship to $\mathrm{B}$ - this means that the investors in A must take care not to be employed by B, or be directors of B, or to have any trading arrangement with B; and (ii) they must likewise make sure that they owe no temporary or permanent duty to any trading partner of B; such as being a director of a major B supplier; and (iii) they must also be sure that company A itself owes no duty to disrupted company B or has any temporary or permanent trading relationship with company B (i.e., company B is an unrelated player in the market competing directly or indirectly with company A). In other words, the investor must not have any direct or indirect relationship with company B which would subject the investor to insider trading restrictions when trading on public company B's stock. The only other issue of concern is that investors in A have a duty to company A itself if these investors use A's non-public information. This duty is not necessarily broken just because the investors use this information for personal gain. The key is to ensure that the investors do not misappropriate the information about $\mathrm{A}$.

When venture investors invest in a new company, it is typically the case that they request many investor rights as part of their investment. These investor rights are summarized in a document called a "terms sheet" for the investment offer. The terms sheet becomes the basis for all final investment documents. To make sure that the venture investors in A are not deemed to have misappropriated information by later trading on such information learned through their company A-related investment activities, venture investors should simply request explicit permission to use such information as part of their investment term sheets. ${ }^{2}$

\subsection{US Supreme Court}

The reader should note that it is not enough to read the SEC statutes, one must also study how the courts interpret the law. Here we are fortunate to be guided by a whole series of U.S. Supreme Court judgments that reinforce our viewpoint.

Cady, Roberts (1961) established the duty of some parties such as a brokerage firm employee, to either disclose material, non-public information or abstain from trading. Two other cases: Investors Management Co (1971) and Oppenheimer and Co (1976) gave further weight to this case and better defined the types of insider information triggering the "disclose or abstain to trade" prohibitions.

\footnotetext{
${ }^{2}$ One venture investment organization who gave feedback on the ideas in this paper has started using the following language in the "Confidentiality" sections of their terms sheets: "It is understood and agreed that the Investors may learn material non-public information about third-party public and/or private companies who are competitors, suppliers, investors, partners, or customers of the Company as a result of their serving on the Board, or as an investor in the Company. The Company hereby expressly disclaims any and all representations and warranties with respect to such material non-public information, including but not limited to warranties of accuracy and completeness; but grants to Investors unrestricted rights to use such information about third parties, if any, without notifying the Company."
} 
In Chiarella (1980), and Dirks (1983), the Supreme Court reinforced the line of reasoning, rejecting the contention that "mere possession of material nonpublic information" imposes upon the possessor a fiduciary duty to disclose or abstain from trading. In doing so, the Supreme Court reaffirmed that for a Section 10(b) violation there must be a special relationship between the corporation's shareholders and the person trading on inside information.

Newman (1981) and Materia (1985) established more clearly the "misappropriation theory". These cases changed the focus of Section 10(b) away from the defrauded purchaser or seller of securities and instead focused on the trader's relationship to the entity from which the information was obtained. Although there was no fraud perpetrated by Newman or Materia against the buyers/sellers of any securities, those cases identified a duty running between the defendants and the entities that were connected in some way to the securities transaction from which the defendants wrongly profited. In our proposed transaction, we stress that the investors in A must take care (inter-alia) to have cleared their relationship with A and by implication with the other investors in A about the use of the information.

Carpenter (1986) expanded on Newman and Materia. There was no confidential information breached related to the corporation's securities. The only breach was that Winans, a writer for the Wall Street Journal (and his tipee Carpenter), misappropriated for personal profit the newspaper's publishing schedule giving them information about stocks that were to be covered in its "Heard on the Street" column. The Second Circuit Court used Carpenter to increase the scope of misappropriation theory related to securities fraud, but the US Superior Court was split and issued no opinion on the securities fraud aspects of the case. Instead, Carpenter was convicted of mail fraud.

O'Hagan (1997) is the latest Supreme Court ruling and defines current US law. It reaffirmed the misappropriation theory and "outlaws trading on the basis of nonpublic information by a corporate 'outsider' in breach of a duty owed not to a trading party, but to the source of the information." The majority of the Supreme Court justices conceded that "if Mr. O'Hagan had informed his law firm of his intention to use the misappropriated information to trade on the target stock, there would have been no Section 10(b) violation". Justice Thomas pointed out that the fraud was to a third party - and not to a party to the securities transaction. Thus the justices explicitly discuss situations that encompass the strategies proposed in this paper.

In summary, the long line of judgments of the Supreme Court appear to indicate that, at this point in time, an investor in a disruptive innovating company A can use "material, nonpublic information" to trade in stock of disrupted rival company B under Section 10(b) of the Securities Exchange Act of 1934, provided of course that the investor has no conflicting fiduciary duty to either firm.

\section{Discussion}

According to March (1991) and Levinthal and March (1993), entrepreneurs find their opportunities for innovation are limited because investors in entrepreneurial projects find it hard to achieve satisfactory returns on projects that break new ground, such as development of new products, processes, markets and/or new organizational forms. Even though these investments may have significant impacts in the markets where they appear 
that may benefit consumers and society, they carry high risk (Bebchuk and Fershtman, 1994) and there are reasons to assume that the internal rates of return may be poor (Teece, 1984; Leonard-Barton, 1992; Burgelman, 1994; Barnett et al., 1994). The problems do not just relate to ventures in the domestic arena, they could be applied to situations of internationalization (Jaffe et al., 2005).

This paper explains how investors in entrepreneurial projects can raise their returns. This not only benefits the investors, and entrepreneurs that are looking for financing, but ultimately the final consumer of the new, disruptive product or service. Our core idea is options management, but our approach differs from the previous literature on real options in the strategy field. We identify the availability of an embedded real option that is present within investments made by early stage investors in disruptive innovative companies. In our paper, this embedded real option to purchase a derivative in a stock substitute bridges the financial and real asset markets by enabling the investors in disruptive company A to create a contract, effectively, with the customers of disrupted company B just prior to the point in time when the disruption will occur.

Our suggested use of financial options instruments to bridge the financial and real asset markets supports the real options approach to increasing value by flexibility as noted by Leslie and Michaels (1997), Dixit and Pindyck (1994, 1997), and Luerhman (1997, 1998). And our ideas are consistent with the logic of firms developing a portfolio of new ideas (Bartlett and Ghoshal, 1993; MacMillan and McGrath, 2000; McGrath and MacMillan, 2000; Boisot and MacMillan, 2005).

The idea that investors can use financial markets to increase value has a parallel line of reasoning in the alliance literature. Writers such as Teece (1996) have long stressed the importance of complementary assets and their role in risky projects has been explored (Kogut, 1991; Bowman and Hurry, 1993; Sanchez, 1993; and most notably, Miller and Waller, 2003; McGrath, 1999). Yet partnerships have a downside. They are notorious for their lack of clear governance mechanisms when compared with ownership contracts. The success of alliances formed by firms is reported by managers to be as low as 50\% (Kale et al., 2002). There is a chance that the agreement will incur high costs if a party does not deliver. The relatively high rate of alliance failure can be associated with the specific relational risks of partner opportunism, conflicting objectives, and misunderstandings that arise in addition to the standard performance risks that all entrepreneurial business activities face (Das and Teng, 2000). The need to create mechanisms such as trust to overcome these risks has been stressed by Powell (1990) and Ring and Van de Ven (1992). Although contracts can be written to try to prevent such events, the contracts are typically incomplete and hard to enforce.

Our use of financial options markets to raise value does not go against any of these moves, but has many intrinsic benefits that are not shown in alliance contracts. Options contracts are simple, well regulated and have the merit that there is a secure counter party that delivers the benefits.

\subsection{Practical considerations}

Can our suggested practices really work, and is it important for investors to add protections we suggest to their investment documents? We have noted that the frequency 
of the opportunity for the investor to undertake the proposed financial plays is rare. The new venture must have a new product, process, channel of distribution or some other angle that is clearly "disruptive" to established firms. Most new ventures never find themselves in that position, but a few do. For these few, our strategy is meaningful. The returns are frequency multiplied by value, frequency may be low but value is very large and so the potential profits from our strategy are significant.

Our work helps add to the standard terms all investors should consider when structuring their investments. It is common for investors to include covenants in their terms sheets to handle situations where the occurrence is rare, but where the financial impacts are significant. These covenants become part of the boilerplate used for all investments. Examples of such boilerplate covenants include: redemption provisions, requirements for key man insurance, S-3 registration rights, auditing requirements, penalties for violating confidentiality terms, and so on. To take advantage of the opportunities we describe, given the financial impact preserved by protecting for this possibility, we propose that investors draft boilerplate language (such as that cited in footnote 2 above) to cover this situation as well.

We have undertaken extensive discussions with entrepreneurs and venture investors about our proposed ideas. They are very guarded (for tax and other reasons) about admitting to undertaking our strategy. But a few have clearly done so to a considerable profit. The majority of investors we meet believe our ideas are practical and will work, for they can clearly point to situations in the past where they could have made the kinds of profits we are discussing. Moreover, these investors are using provisions, such as the one cited, in their term sheets for new investments. Actions speak loudly; our proposal is not a mere academic pipedream but something that has practical meaning.

\section{Conclusions}

In the last decade capital markets have developed considerably and are more willing to finance risky young ventures. This has gone a long way to improving the ability of entrepreneurs to raise financing for ventures that will improve society by improving consumer choice. The emergence of NASDAQ in the USA, AIM in London and the Neuer Markt in Germany have provided a forum where owners of new firms can capitalise on future uncertain profit streams and raise immediate capital on their exploratory ideas.

This paper goes one step further by explaining how vibrant capital markets can provide another effective mechanism for assisting ventures. When private investors fund a venture that poses a significant entry threat to established firms, the investor may purchase a put option on its rival and so secure additional returns to its as yet unannounced innovation. Upon announcement, the reaction of the market in terms of the stock price generates an immediate gain for the investor in the innovating firm. The investor does not have to wait for project completion before reaping any reward. This added feedback is potentially short and very powerful.

In the context of the entrepreneurship literature we place our contribution as a new strand of thinking that bridges entrepreneurship, finance and strategy. Our paper provides 
guidance on the moral, legal-regulatory and practical aspects of the proposed strategies. We believe that we have given a new dimension of financial strategy for venture finance and a fruitful avenue for discussion and research.

\section{Acknowledgements}

We acknowledge valuable comments from the editor and two anonymous reviewers of this journal, from Tom Begley, Max Boisot, Phil Bromiley, Rudy Durand, Daniel Giamouridis, Mike Lubatkin and Brian Wright and from seminar participants at the Wharton School, Haas School, Cass Business School, Kent Business School, the Academy of Management, Toronto. We also thank the Design Council of the UK for their support in case writing, and the Haas Business School and Wharton Business School, with special mention to "Mac" MacMillan for providing the right intellectual climate for idea generation and his encouragement. The first author is responsible for the core ideas and themes of the paper, the second and third authors have contributed heavily to the paper development and finding examples, and the last author has contributed key insights into the legal position and the role of venture funds. We acknowledge funding assistance for the research from the ESRC-Evolution of Business Knowledge Programme.

\section{References}

Aboody, D., Lev, B., 2000. Information asymmetry, R\&D, and insider gains. Journal of Finance 55 (6), $2747-2766$.

Arrow, K., 1962. Economic welfare and the allocation of resources for inventions. In: Nelson, R. (Ed.), The Rate and Direction of Inventive Activity. Princeton University Press, Princeton, NJ.

Ayres, I., Bankman, J., 2001. Substitutes for insider trading. Stanford Law Review 54, 235-254.

Barnett, W.P., Greve, H.R., Park, D.Y., 1994. An evolutionary model of organizational performance. Strategic Management Journal 15, 11-28 (Winter).

Bartlett, C.A., Ghoshal, S., 1993. Beyond the m-form: towards a managerial theory of the firm. Strategic Management Journal 14, 23-46 (Winter).

Bebchuk, L.A., Fershtman, C., 1994. Insider trading and the managerial choice among risky projects. Journal of Financial and Quantitative Analysis 29 (1), 1-14 (March).

Black, F., Scholes, M., 1973. The pricing of options and corporate liabilities. Journal of Political Economy 81 (3), $637-654$.

Boisot, M., MacMillan, M., 2005. Cross epistemological boundaries: managerial and entrepreneurial approaches to knowledge management. Long Range Planning 37 (6), 505-524.

Bowman, E.H., Hurry, D., 1993. Strategy through the options lens: an integrated view of resource investments and the incremental-choice process. Academy of Management Review 18 (4), 760-782.

Burgelman, R.A., 1994. Fading memories: a process theory of strategic business exit in dynamic environments. Administrative Science Quarterly 39 (1), 24-56.

Bygrave, W., 1989. Early rates of return of 131 venture capital funds started 1978-1984. Journal of Business Venturing 4, 93-105.

Chan, S., Kensinger, J., Keown, A., Martin, J., 1997. Do strategic alliances create value. Journal of Financial Economics 46 (2), 199-221.

Chen, S.-S., Ho, K.W., Ik, K.H., Lee, C., 2002. How does strategic competition affect firm values? A study of new product announcements. Financial Management 3, 67-84.

Christensen, C.M., 1997. The Innovators Dilemma: When New Technologies Cause Great Firms to Fail. Harvard Business School Press, Boston. 
Coase, R., 1960. The problem of social cost. Journal of Law and Economics 3, 1-44.

Das, T., Teng, B., 2000. Instabilitites of strategic alliances: an internal tensions perspective. Organization Science 11 (1), 77-101.

Das, Sen, S.P., Sengupta, S., 1998. Impact of strategic alliances on firm valuation. Academy of Management Journal 41 (1), $27-41$.

Dixit, A.K., Pindyck, R.S., 1994. Investment Under Uncertainty. Princeton University Press, Princeton, NJ.

Dixit, A.K., Pindyck, R.S., 1997. The options approach to capital investment. In: Brown, John Seeley (Ed.), Seeing Things Differently: Insights on Innovation. Harvard Business Press, Boston, MA.

Fama, E., 1991. Efficient capital markets: II. The Journal of Finance 46, 1575-1614.

http://www.ee-online.com, 29th January 2001.

Hirshleifer, J., 1961. On the economics of transfer pricing. Journal of Industrial Economics 10, $215-232$.

$\mathrm{Hu}$, J., Noe, T., 2001. Insider trading and managerial incentives. Journal of Banking and Finance 25, 681 - 716.

Jaffe, E.D., Nebenzahl, I.D., Schorr, I., 2005. Strategic options of home country firms faced with MNC entry. Long Range Planning 38, 1.

Jeng, L.A., Metrick, A., Zeckhauser, R., 1999. The profits to insider trading. National Bureau of Economic Research working paper number 6913.

Kale, P., Dyer, J., Singh, H., 2002. Alliance capability, stock market response, and long-term alliance success: the role of the alliance function. Strategic Management Journal 23, 747-767.

Kleiman, R.T., Shulman, J.M., 1992. The risk-return attributes of publicly traded venture capital. Journal of Business Venturing 7, 195-208

Kogut, B., 1991. Joint ventures and the option to expand and acquire. Management Science 37 (1), 19-33.

Koh, J., Venkatraman, N., 1991. Joint venture formations and stock market reactions: an assessment in the information technology sector. Academy of Management Journal 34 (4), 869-892.

Leonard-Barton, D., 1992. Core capabilities and core rigidities: a paradox in managing new product development. Strategic Management Journal 13, 111-125 (Summer).

Leslie, K.J., Michaels, M.P., 1997. The real power of real options. McKinsey Quarterly (3), 4-22.

Levinthal, D.A., March, J.G., 1993. The myopia of learning. Strategic Management Journal 14, 95-112 (Winter).

Luerhman, T., 1997. What's it worth? A general manager's guide to valuation. Harvard Business Review 75 (3), $132-142$.

Luerhman, T., 1998. Strategy as a portfolio of real options. Harvard Business Review 76 (5), 89-99.

MacMillan, I.C., McGrath, R.G., 2000. Assessing technology projects using real options reasoning. Research Technology Management 43 (4), 35-49.

Mainigart, S., De Waele, K., Wright, M., Robbie, K., Desbrieres, P., Sapienza, H.J., Beekman, A., 2002. Determinants of required return in venture capital investments: a five country study. Journal of Business Venturing 17, 291-312.

Manne, H.G., 1966. In defense of insider trading. Harvard Business Review 44 (6), 113-123.

March, J.G., 1991. Exploration and exploitation in organisational learning. Organization Science 2 (1), $71-87$.

Mason, C.M., Harrison, R.T., 2002. Is it worth it? The rates of return from informal venture capital investments. Journal of Business Venturing 17, 211-236.

McGrath, R.G., 1999. Falling forward: real options reasoning and entrepreneurial failure. Academy of Management Review 24 (1), 13-30.

McGrath, R.G., MacMillan, I.C., 2000. The Entrepreneurial Mindset: Strategies for Continuously Creating Opportunity in an Age of Uncertainty. Harvard Business School Press, Boston, MA.

Miller, K.D., Waller, H.G., 2003. Scenarios, real options and integrated risk management. Long Range Planning 36 (1), 93- 107.

Pagno, M., Roell, A., 1966. Transparency and liquidity: a comparison of auction and dealer markets with informed trading. Journal of Finance 51 (2), 579-611.

Powell, W.W., 1990. Hybrid organizational arrangements: new forms of transitional arrangements. California Management Review 30 (1), 67-87.

Ring, P.S., Van de Ven, A.H., 1992. Structuring co-operative relationships between organizations. Strategic Management Journal 13 (7), 483-498.

Sanchez, R., 1993. Strategic flexibility, firm organization, and managerial work in dynamic markets: a strategic options perspective. Advances in Strategic Management 9, 251-291. 
Sundaram, A., John, T., John, K., 1996. An empirical analysis of strategic competition and firm values: the case of R\&D competition. Journal of Financial Economics 40, 459-486.

Teece, D.J., 1984. Economic analysis and strategic management. California Management Review 26 (3), $87-110$. Teece, D.J., 1996. Firm organization, industrial structure, and technological innovation. Journal of Economic Behavior and Organization 31 (2), 193-224.

Von Hippel, E., 1986. Lead users: a source of novel product concepts. Management Science 32, 791 - 805 (July).

Whinston, M., Collins, S., 1992. Entry and competitive structure in deregulated airline markets: an event study analysis of People Express. Rand Journal of Economics 23 (4), 445-462. 